\title{
La Royal Navy pendant les guerres de la Révolution et de l'Empire (1793-1815)
}

Essai de parcours bibliographique

\section{Marianne Czisnik}

\section{(2) OpenEdition}

\section{Journals}

Édition électronique

URL : https://journals.openedition.org/ahrf/10182

DOI : 10.4000/ahrf.10182

ISSN : 1952-403X

Éditeur :

Armand Colin, Société des études robespierristes

Édition imprimée

Date de publication : 15 mars 2006

Pagination : 177-184

ISSN : 0003-4436

Référence électronique

Marianne Czisnik, «La Royal Navy pendant les guerres de la Révolution et de l'Empire (1793-1815) », Annales historiques de la Révolution française [En ligne], 343 | janvier-mars 2006, mis en ligne le 01 mars 2009, consulté le 24 avril 2022. URL : http://journals.openedition.org/ahrf/10182 ; DOI : https:// doi.org/10.4000/ahrf.10182

Ce document a été généré automatiquement le 24 avril 2022.

Tous droits réservés 


\title{
La Royal Navy pendant les guerres de la Révolution et de l'Empire (1793-1815)
}

\author{
Essai de parcours bibliographique
}

\section{Marianne Czisnik}

La bibliographie sur la Royal Navy pendant la période révolutionnaire et impériale s'est élargie à de nouveaux domaines dans les dernières décennies. Ce mouvement trouve son origine dans une réaction contre la vieille histoire navale telle qu'elle fut écrite par les historiens de la fin du XIX siècle. Ces derniers s'intéressaient principalement aux batailles navales, en particulier à leur dimension tactique, et dans une certaine mesure à l'arrière-plan politique et à leurs conséquences. En s'éloignant d'une perspective aussi réductrice, l'histoire navale a, plus récemment, élaboré une vision plus riche du passé naval de la Grande-Bretagne. Depuis les années 1960, certains historiens ont commencé à étudier l'administration de la Navy. Un ouvrage révolutionnaire à cet égard fut celui de Daniel A. Baugh en $1965^{1}$. Des éléments centraux dans le fonctionnement de la Royal Navy, comme l'approvisionnement des navires et le travail dans les chantiers navals, ont récemment fait l'objet de recherches approfondies. Des études d'histoire culturelle, sur l'identité navale britannique et l'impact culturel de la Navy en tant qu'institution, ont encore étendu le champ de l'histoire navale. Des objets comme les céramiques ont aussi attiré l'attention des chercheurs, tandis que les questions de tactiques navales ont été peu à peu délaissées par les historiens contemporains. Des développements récents dans la recherche semblent indiquer que ce déséquilibre est en train d'être corrigé, et que les études navales deviennent de plus en plus interdisciplinaires. Cet article présente donc les développements récents dans l'historiographie de la Royal Navy entre 1793 et 1815 . Ce faisant, on abordera les principaux thèmes ayant émergé dans les dernières décennies: la politique et la stratégie, l'administration, la biographie, la tactique et les opérations navales et pour finir la culture.

Politique et stratégie 
2 Pour situer la Royal Navy dans son contexte international, la lecture de l'ouvrage de Jan Glete est recommandée ${ }^{2}$. Les relations navales entre la France et l'Angleterre ont fait l'objet d'une conférence, publiée dans les Journées franco-britanniques d'histoire maritime.

3 Sur la Royal Navy en général, de nombreuses histoires existent, dont la qualité est variable. L'ouvrage de N.A.M. Roger, The Command of the Ocean, est sans doute le plus important d'entre eux ${ }^{3}$. Ce livre récent, qui a été à juste titre couvert d'éloges, s'inscrit dans la continuité du précédent ${ }^{4}$. Un troisième volume est en préparation, couvrant la période allant de 1815 à aujourd'hui. Ce travail n'aborde pas seulement des thèmes comme les navires, les officiers, les équipages et les opérations navales, mais aussi l'histoire administrative et sociale de la marine. Dans le champ de l'histoire navale, N.A.M. Rodger est une autorité indiscutable, à l'érudition impressionnante, mais aussi aux réelles qualités stylistiques. Pour avoir un aperçu des sources archivistiques, plusieurs outils sont disponibles, et tout d'abord l'édition des British Naval Documents 1204-19605. Ce gros volume couvre non seulement une longue période chronologique, mais aborde aussi beaucoup de thèmes, bien au-delà de la politique et de la stratégie : la tactique, l'administration ou le personnel naval sont ainsi évoqués. On peut faire la même remarque à propos du recueil d'essais publiés sous la direction de John B. Hattendorf, où sont étudiées des questions comme "The Science and Practice of Navigation " ou "The Maritime Legacy of Empire ", par des historiens déjà cités, comme Daniel A. Baugh et N.A.M. Rodger ${ }^{6}$. Une vision plus synthétique de l'histoire de la Royal Navy est proposée par Richard Harding, dans deux courts ouvrages, qui sont surtout centrés sur les origines de la marine royale, tandis que la période des guerres révolutionnaires et impériales n'est traitée que de façon superficielle ${ }^{7}$. Un article récent de N.A.M. Rodger permet d'avoir une bonne vue d'ensemble sur l'historiographie de la Royal Navy au XVIII ${ }^{\mathrm{e}}$ siècle ${ }^{8}$.

4 Depuis les années 1980, les auteurs ont exploré les domaines spécifiques des politiques et des stratégies navales. L'importance des West Indies pour la Grande-Bretagne lors des guerres révolutionnaires, et le rôle particulier de la Navy pour y garantir l'influence britannique, ont été étudiés par Michael Duffy ${ }^{9}$. Certains historiens de la marine ont centré leurs études sur les politiques de blocus, en particulier celui de Brest ${ }^{10}$. Ceci s'explique par un fait simple : c'est sans doute au large du port breton que le blocus des ports français fut le plus efficace durant la période 1793-1815. Ajoutons en outre que la menace que représentait Brest s'explique en particulier par la proximité des côtes britanniques.

5 La collecte de renseignements représentait bien évidemment une part importante de la politique en temps en guerre. Steven E. Maffeo a tenté de traiter ce sujet sur l'ensemble de la période 1793-1815, mais n'entre pas vraiment dans les détails ${ }^{11}$. On peut aussi lire les travaux de Frank Kitchen et de W.H. Clements sur cette question ${ }^{12}$. On évoquera plus loin les travaux portant sur l'influence des renseignements dans l'issue de campagnes navales spécifiques.

L'administration

6 On entendra ici l'administration dans un sens étendu, depuis les problèmes techniques jusqu'aux questions de personnel. Ces deux thèmes sont bien traités dans un livre de Brian Lavery, par ailleurs abondamment illustré ${ }^{13}$. La dimension technique de l'histoire navale est abordée dans des études sur les chantiers navals et les bateaux. Sur les premiers, l'étude de Roger Morriss est une référence ${ }^{14}$, dont Jonathan G. Coad a prolongé et élargi les conclusions à une période plus longue ${ }^{15}$. Paul Webb a fait le lien 
entre les problèmes techniques et la politique, tandis que Philip MacDougall a fait une étude de cas originale sur les chantiers navals de Malte ${ }^{16}$. C'est une nouvelle fois à Roger Morriss que l'on doit un travail plus global sur ces questions. Dans un livre récent, il examine avec beaucoup de finesse la signification politique, administrative et financière des chantiers navals en Grande-Bretagne ${ }^{17}$.

Sur les navires eux-mêmes, la littérature est foisonnante. The Sailing Navy List est un outil de travail indispensable, qui fournit la liste des bateaux en fonction de leur classe et du moment de leur mise en service. Le tout est muni d'un index fort utile ${ }^{18}$. Concernant la construction des bâtiments, un livre édité par Robert Gardiner analyse les différents types de bateaux, depuis la chaloupe jusqu'au bâtiment de ligne. La conception des bateaux, leur construction, le gréement et le gréage, les canons, font l'objet de chapitres propres. Sur une longue période, depuis 1600 jusqu'à la première guerre mondiale, on peut lire le livre de W.E. May, tandis que Chris Ware traite de la période 1687-1854 et David R. MacGregor aborde une durée encore plus longue, allant de 1600 jusqu'à aujourd'hui ${ }^{19}$. Les frégates ont tout particulièrement suscité l'attention des historiens, notamment de Robert Gardiner, qui leur a consacré trois livres ${ }^{20}$. Paul Webb tente de comprendre le rôle des frégates dans les guerres révolutionnaires, en s'intéressant à leur disponibilité concrète ${ }^{21}$. Les livres portant sur les vaisseaux de ligne sont souvent associés à la carrière de l'Amiral Nelson. C'est le cas d'un ouvrage de Brian Lavery, ou encore de ceux de Peter Goodwin et d'Anthony Deane ${ }^{22}$. Si les deux premiers sont avant tout intéressés par les caractéristiques techniques des navires, l'histoire de l'Agamemnon par A. Deane est davantage un récit. Sur les vaisseaux de ligne en général, on peut aussi consulter un autre ouvrage de P. Goodwin, Men o'War ${ }^{23}$.

La vie et le travail à bord des bateaux sont traités dans un livre de N.A.M. Rodger qui est déjà un classique du genre ${ }^{24}$. Les lecteurs intéressés par les archives pourront se reporter à un outil qu'a constitué Brian Lavery ${ }^{25}$, soit une sélection variée de règlements et d'instructions venus de l'amirauté, des journaux de médecins de bord, ainsi que des documents portant sur l'organisation à bord des bateaux, comme la discipline et les sanctions. Les questions d'éducation, de soin médical et de conditions de travail au sein de la Navy ont été abordées dans plusieurs articles récents du Mariner's Mirror ${ }^{26}$. Mentionnons aussi l'édition du journal d'un marin, Jacob Nagle ${ }^{27}$. Dans les années 1990, les travaux sur les femmes navigantes sont venus enrichir le tableau, même si dans l'ouvrage édité par Margaret S. Creighton et Lisa Norling, la Navy n'est pas centrale, contrairement à celui de Suzanne J. Stark ${ }^{28}$.

Biographies

9 L'attention des biographes s'est principalement concentrée sur les officiers. David Syrett et R.L. Di Nardo offrent un bon survol de leurs carrières ${ }^{29}$. Les officiers sont classés dans l'ordre alphabétique et une notice abrégée résume la carrière de chacun. Tom Wareham s'est intéressé à un groupe professionnel en particulier ${ }^{30}$. Des éditions récentes des archives personnelles de certains officiers permettent d'avoir une vision originale de la vie et de la carrière au sein de la Navy ${ }^{31}$. Toutefois, l'essentiel de la recherche et des publications récentes se sont concentrées sur les amiraux. Peter Le Fevre et Richard Harding ont édité un recueil utile de courtes biographies ${ }^{32}$, et l'on peut aussi mentionner, sur des amiraux britanniques ayant exercé pendant les French Wars, les biographies de Sir Charles Cotton, de Collingwood ou encore de Sir Sidney Smith ${ }^{33}$.

10 La figure de Nelson, le plus grand amiral ayant combattu pendant cette période, continue à exercer un attrait inégalé sur les biographes. Le livre de Tom Pocock à 
longtemps dominé le marchés ${ }^{34}$, jusqu'à ce que Christopher Hibbert ouvre la voie à une nouvelle vague de biographies sur Nelson ${ }^{35}$. Son livre n'est pas très bon, mais à l'exception de la biographie ancienne de Carola Oman publiée en $1947^{36}$, c'était le premier à être muni d'un sérieux appareil critique. C. Hibbert a donc établi une nouvelle norme, et plusieurs biographes lui emboîtèrent ensuite le pas, comme Terry Coleman, Edgar Vincent, Andrew Lambert, ou encore John Sugden ${ }^{37}$. Le domaine a encore été enrichi en 2005 par une édition des correspondances de Nelson par Colin White ${ }^{38}$, et par une nouvelle biographie, appelée à devenir celle de référence, qui est l'œuvre de Roger $\mathrm{Knight}^{39}$. La commémoration du grand homme, à travers les portraits, les monuments et autres vestiges, est évoquée dans deux livres de Colin White ${ }^{40}$. Mon propre Horatio Nelson. A Controversial Hero ${ }^{41}$, s'intéresse aux aspects les plus contestés de la vie de Nelson, analysant la place qu'il occupe dans l'historiographie et dans l'imagerie populaire.

La tactique et les opérations navales

11 Pendant la période durant laquelle la tactique navale était délaissée par les historiens, cette question ne suscitait l'intérêt que des érudits locaux. Le plus remarquable, parmi ceux qui s'y intéressaient sérieusement, est Brian Tunstall. Durant sa vie, il a constitué une collection considérable de signaux et d'ordres, sur la base desquels il a écrit un travail exhaustif, qui fut édité un quart de siècle après sa mort par Nicolas Tracy ${ }^{42}$. Bien que ce travail ne prenne pas beaucoup en compte l'historiographie, sans même parler des ouvrages récents, et bien qu'à certains moments la description soit noyée sous la masse des détails, il rend accessible quantité de matériaux, qui ont permis de ranimer les débats universitaires sur la tactique navale. N.A.M. Rodger ou Ruddock Mackay ont ainsi étudié à nouveaux frais les tactiques navales pendant les guerres de 1793 à $1815^{43}$.

12 L'intérêt grandissant du public envers les batailles navales elles-mêmes a conduit à la publication de recueils sur des épisodes particuliers ${ }^{44}$. Les comptes rendus de certaines batailles célèbres par des témoins oculaires ont fait également l'objet d'anthologies ${ }^{45}$. Enfin, réévaluant l'opinion commune qui souligne l'aspect décisif de ces combats, Edward Ingram argumente dans le sens d'une inefficacité des batailles menées par Nelson ${ }^{46}$.

13 Le rôle de la Royal Navy pendant les guerres révolutionnaires de 1793 à 1802 est traité par Robert Gardiner ${ }^{47}$. Michael Duffy et Roger Morriss remettent les combats dans leur contexte, y compris culturel, prenant en compte le théatre, les commémorations ou les objets qui sont parvenus jusqu'à nous. Sur des campagnes spécifiques, mentionnons les articles de Dennis A. Wheeler et de Michael Duffy ${ }^{48}$, ce dernier apportant une contribution importante à l'histoire du renseignement pendant cette période. J'ai moimême étudié l'effet de la Bataille du Nil en 1798 sur l'opinion publique et la culture ${ }^{49}$. La meilleur étude d'ensemble de cette bataille en langue anglaise reste l'ouvrage de Brian Lavery publié en $1998^{50}$. Sur la victoire de Nelson à Copenhague, qui rend justice au point de vue danois, on peut enfin lire la bonne étude de Ole Feldbæk ${ }^{51}$.

Sur la période suivante, celle des guerres napoléoniennes allant de 1803 à 1815, l'intérêt des historiens s'est concentré sur la campagne, puis la bataille de Trafalgar. Alan Schom a renouvelé l'étude de la campagne qui a mené à la bataille dans un livre fouillé ${ }^{52}$, de même que Nicholas Tracy et Robert Gardiner ${ }^{53}$. Une floraison de livres sont apparus dans la foulée du bicentenaire de la grande victoire de Nelson à Trafalgar. Le meilleur est celui de Tim Clayton et Phil Craig ${ }^{54}$, mais l'on trouve d'éclatants témoignages de contemporains dans le livre de Roy Adkins ${ }^{55}$. Tom Pocock a su profiter du 
renouvellement de la curiosité envers le renseignement pour écrire un ouvrage qui est intéressant plus du point de vue des documents reproduits, utilisés pour produire un récit captivant, que de l'analyse elle-même ${ }^{56}$. J'ai moi-même réexaminé des sources négligées pour proposer une vision originale de la bataille elle-même ${ }^{57}$. Quelques études d'histoire navale abordent aussi la période d'après Trafalgar, notamment celle de Richard Woodman ${ }^{58}$. Christopher D. Hall affirme quant à lui que «peu de batailles, avant ou après, ont vu la question de la puissance navale avoir un impact aussi profond sur une campagne terrestre $»^{59}$.

La culture

L'impact culturel de la Royal Navy, en particulier durant les guerres contre la France, a été analysé par Michael Duffy et Roger Morris ${ }^{60}$, mais depuis plus récemment encore ces thématiques ont occupé le devant de la scène. Jane Austen, la fiction maritime, et l'œuvre de Richard Hakluyt, Daniel Defoe, Tobias Smollett, Jane Austen and Captain Marryat, ont ainsi suscité l'attention des historiens ${ }^{61}$. Au-delà de la manière dont la Navy est évoquée dans la littérature, le livre de Margarette Lincoln « considère la Navy comme une présence culturelle dans la sphère publique $\aleph^{62}$. Ma propre étude à paraître sur Nelson examine notamment les nombreux objets fabriqués pour célébrer ses succès.

\section{NOTES}

1.Daniel BAUGH, British Naval Administration in the Age of Walpole, Princeton, Princeton University Press, 1965.

2.Jan GLETE, Navies and Nations: Warships, Navies and State Building in Europe and America, 1500-1866, Stockholm, Almquist \& Wiksell International, 1993.

3.N.A.M. RODGER, The Command of the Ocean. A Naval History of Britain 1649-1815, London, Allen Lane, 2004.

4.N.A.M. RODGER, The Safeguard of the Sea 660-1649, London, Allen Lane, 1997.

5.British Naval Documents 1204-1960, Aldershot, Scolar for the Navy Records Society, 1993, éd. John B. HATTENDORF, R.J.B. KNIGHT, A.W.H. PEARSALL, N.A.M. RODGER and Geoffrey TILL. 6.John B. HATTENDORF, éd., Maritime History, 2 vols., Melbourne, Florida, Krieger Publishing Company, 1996-1997.

7.Richard HARDING, Seapower and Naval Warfare 1650-1830, London, UCL Press, 1999 ; The Evolution of the Sailing Navy 1509-1815, Basingstoke, Macmillan, 1995.

8.N.A.M. RODGER, « Recent books on the Royal Navy of the Eighteenth Century », The Journal of Military History, 63 (1999), p. 683-703.

9.Michael DufFY, Soldiers, Sugar and Sea Power : The British Expeditions to the West Indies and the War against Revolutionary France, Oxford, Clarendon Press, 1987.

10.Michael STEER, «The Blockade of Brest and the Victualling of the Western Squadron, 1793-1805 ", dans The Mariner's Mirror, 76 (1990), p. 307-316 ; Richard SAXBY, « The Blockade of Brest in the French Revolutionary War ", dans The Mariner's Mirror, 78 (1992), p. 25-35 ; Michael DuFfY, « The Establishment of the Western Squadron as the Linchpin of British Naval Strategy » dans idem. (ed.) Parameters of British Naval Power, 
1650-1850, Exeter, University of Exeter Press, 1992 ; Roger MORRISS, The Channel Fleet and the Blockade of Brest, 1793-1801, Aldershot, Ashgate, 2001. Susanna FISHER a montré comment les renseignements militaires étaient collectés pour mettre en œuvre le blocus : "Captain Thomas Hurd's Survey of the Bay of Brest during the Blockade in the Napoleonic Wars » dans The Mariner's Mirror, 79 (1993), p. 293-304.

11.Steven E. MAFFEO, Most Secret and Confidential : Intelligence in the Age of Nelson, London, Chatham, 2000.

12.Frank KITCHEN, « The Napoleonic War Coast Signal Stations » dans The Mariner's Mirror, 76 (1990), p. 337-344 ; W. H. CLEMENTS, Towers of Strength : Martello Towers Worldwide, Barnsley, Leo Cooper, 1999.

13.Brian LAVERY, Nelson's Navy: Its Ships, Men and Organisation 1793-1815, London Conway Maritime, 1989 pour la première édition, et fréquemment réédité depuis.

14.Roger MORRISS, The Royal Dockyards During the Revolutionary and Napoleonic Wars, Leicester, Leicester University Press, 1983.

15.Jonathan G. COAD, The Royal Dockyards 1690-1850: Architecture and Engineering Works of the Sailing Navy, Aldershot, Scolar for the Royal Commission of Historical Monuments of England, 1989.

16.Paul WEBB, «Construction, repair and maintenance in the battle fleet of the Royal Navy, 1793-1815 ", dans The British Navy and the Use of Naval Power in the Eighteenth Century, ed. Jeremy BLACK and Philip WOODFINE, Leicester, Leicester University Press, 1988, p. 207-219 ; Philip MACDOUGALL, « The Formative Years. Malta Dockyard, 1800-1815 » dans The Mariner's Mirror, 76 (1990), p. 205-213.

17.Roger MORRISS, Naval Power and British Culture, 1760-1850. Public Trust and Government Ideology, Aldershot, Ashgate, 2004.

18.David LYON, The Sailing Navy List. All the Ships of the Royal Navy - Built, Purchased and Captured - 1688-1860, London, Conway Maritime Press, 1993. Ce volume peut être complété par David HEPPER, British Warship Losses in the Age of Sail, Rotherfield, East Sussex, Jean Boudriot, 1994.

19.W. E. MAY, avec des compléments de Simon STEPHENS, The Boats of Men of War, $2^{\mathrm{e}}$ éd. révisée, London, Chatham, 1999 ; Chris WARE, The Bomb Vessel : Shore Bombardment Ships in the Age of Sail, London, Conway Maritime Press, 1994 ; David R. MACGREGOR, The Schooner : Its Design and Development from 1600 to the Present, London, Chatham, 1997. 20.Robert GARDINER, The First Frigates. Nine-pounder and Twelve-pounder Frigates 1748-1815, London, Conway Maritime Press, 1992, The Heavy Frigates.18-Pounder Frigates. Vol. 1 1778-1800, London, Conway Maritime Press, 1994 et Frigates of the Napoleonic Wars, London, Chatham, 2000.

21.Paul WEBB, «The Frigate Situation of the Royal Navy 1793-1815 », The Mariner's Mirror, 82 (1996), p. 28-40.

22.Brian LAVERY, Nelson's Fleet at Trafalgar, London, National Maritime Museum, 2003 ; Peter GOoDWIN, Nelson's Ships : A History of the Vessels in which He Served, 1771-1805, London, Conway Maritime Press, 2002 ; Anthony DEANE, Nelson's Favourite : HMS Agamemnon at War 1781-1809, London, Chatham, 1997. Dans la même veine nelsonienne, on peut aussi citer Alan MCGOWAN, HMS Victory : Her Construction, Career and Restoration, London, Caxton Editions, 1999.

23.Peter Goodwin, Men o' War. The Illustrated Story of Life in Nelson's Navy, London, Carlton Books, 2003. 
24.N.A.M. RODGER, The Wooden World. An Anatomy of the Georgian Navy, London, Collins, 1986.

25.Brian LAVERY, Shipboard Life and Organisation, 1731-1815, Aldershot, Ashgate, 1998.

26.H. W. DICKINSON, « The Portsmouth Naval Academy, 1733-1806 », 89 (2003), p. 17-30 ;

Jane BOWDEN-DAN, « Diet, Dirt and Discipline, Medical Developments in Nelson's Navy. Dr John Snipe's Contribution », 90 (2004), p. 260-272 ; Sam wiLlIS, « The High Life, Topmen in the Eighteenth-Century Navy ", 90 (2004), p. 152-166.

27.John C. DANN éd., The Nagle Journal : A Diary of the Life of Jacob Nagle, Sailor, from the Year 1775 to 1841, London, Weidenfeld \& Nicolson, 1988.

28.Margaret S. CREIGHTON and Lisa NORLING éd., Iron Men, Wooden Women : Gender and Seafaring in the Atlantic World, 1700-1920, Baltimore MD, Johns Hopkins University Press, 1996 ; Suzanne J. STARK, Female Tars. Women Aboard Ship in the Age of Sail, London, Pimlico, 1998.

29.David SYRETT et R.L. DI NARDO, The Commissioned Sea Officers of the Royal Navy, 1660-1815, Aldershot, Scolar Press for the Navy Records Society, 1994.

30.Tom WAREHAM, The Star Captains. Frigate Command in the Napoleonic Wars, London, Chatham, 2001.

31.Captain A. CRAWFORD, Reminiscences of a Naval Officer : A Quarter-Deck View of the War Against Napoleon, introduction de Tom Pocock, London, Chatham, 1999 ; Sea Soldier : An Officer of Marines with Duncan, Nelson, Collingwood and Cockburn: The Letters and Journals of Major T. Marmaduke Wybourn RM, 1797-1813, ed. Anne PETRIDES and Jonathan DOWNS, Tunbridge Wells, Parapress, 2000.

32.Peter LE FEVRE et Richard HARDING, Precursors of Nelson. British Admirals of the Eighteenth Century, London, Chatham, 2000. Cette étude traite aussi de la période postérieure à la Révolution française.

33.Paul C. KRAJESKI, In the Shadow of Nelson: The Naval Leadership of Admiral Sir Charles Cotton, 1753-1812, Westport, Conn., Greenwood, 2000 ; Max ADAMS, Admiral Collingwood : Nelson's Own Hero, London, Weidenfeld \& Nicolson, 2005; Tom POcock, A Thirst for Glory : The Life of Admiral Sir Sidney Smith, London, Aurum, 1996.

34.Tom POcock, Horatio Nelson, London, Bodley Head, 1987.

35.Christopher HIBBERT, Nelson. A Personal History, London, Viking, 1994.

36. Carola OMAN, Nelson, 1947.

37.Terry COLEMAN, Nelson: The Man and the Legend, London, Bloomsbury, 2001 ; Edgar VINCENT, Nelson. Love and Fame, New Haven and London, Yale University Press, 2003 ; Andrew LAMBERT, Nelson. Britannia's God of War, London, Faber and Faber, 2004 ; John SUGDEN, Nelson. A Dream of Glory, London, Jonathan Cape, 2004, premier volume d'une biographie qui devrait bientôt en compter deux.

38. Colin white éd., Nelson: The New Letters, London, The Boydell Press, 2005.

39.Roger KNIGHT, The Pursuit of Victory: The Life and Achievements of Horatio Nelson, London, Allen Lane, 2005.

40.The Nelson Companion, ed. Colin WHITE, Stroud, Alan Sutton, 1995 ; Colin WHITE, The Nelson Encyclopaedia, London, Stackpole Books, 2003.

41.Horatio Nelson. A Controversial Hero, London, Hodder Arnold, à paraître

42.Brian TUNSTALL, Naval Warfare in the Age of Sail : The Evolution of Fighting Tactics, 1650-1815, London, Conway Maritime Press, 1990. 
43.N.A.M. RODGER, « Image and Reality in Eighteenth-Century Naval Tactics » dans The Mariner's Mirror, 89 (2003), p. 280-296 ; Ruddock MACKAY, « From Hawke to Nelson : Strategical and Tactical Comparisons » dans The Mariner's Mirror, 91 (2005), p. 24-33. 44.Nicholas TRACY, Nelson's Battles. The Art of Victory in the Age of Sail, London, Chatham, 1996 ; Peter PADFIELD ; Maritime Power and the Struggle for Freedom. Naval Campaigns that shaped the modern world 1788-1851, London, John Murray, 2003.

45.Dean KING, John B. HATTENDORF, Every Man Will Do His Duty : An Anthology of First-Hand Accounts form the Age of Nelson1793-1815, London, Conway Maritime Press, 1997; réédité en 2002.

46.Edward INGRAM, « Illusions of Victory : the Nile, Copenhagen and Trafalgar revisited ", dans Military Affairs, 48 (1984), p. 140-143.

47.Robert GARDINER, Fleet Battle and Blockade : The French Revolutionary War 1793-1797 ; Id., Nelson against Napoleon : From the Nile to Copenhagen, 1798-1801, London, Chatham, 1996 et 1997.

48.Dennis A. WHEELER, « The Influence of the Weather during the Camperdown Campaign of 1797 », dans The Mariner's Mirror, 77 (1991), p. 47-54 ; Michael DUFFY, « British Naval Intelligence and Bonaparte's Egyptian Expedition of 1798 », dans The Mariner's Mirror, 84 (1998), p. 278-290

49.Marianne CZISNIK, « Nelson and the Nile : The Creation of Admiral Nelson's Public Image ", dans The Mariner's Mirror, 88, 2002, p. 41-60.

50.Brian LAVERY, Nelson and the Nile: the naval war against Bonaparte, 1798, London, 1998.

51.Ole FELDBÆK, The Battle of Copenhagen 1801, Barnsley, Leo Cooper, 2002.

52.Alan sсном, Trafalgar. Countdown to Battle 1803-1805, London, Joseph, 1990.

53.Nicholas TRACY, « Sir Robert Calder's Action », The Mariner's Mirror, 77 (1991), p. 259-269 ; Robert GARDINER, The Campaign of Trafalgar, 1803-1805, London, Chatham, 1997. 54.Tim CLAYTON, Phil CRAIG, Trafalgar : the Men, the Battle, the Storm, London, Hodder and Stoughton, 2004.

55.Roy ADKINS, Trafalgar : The Biography of a Battle, London, Little, Brown, 2004.

56.Tom Рососк, The Terror Before Trafalgar: Nelson, Napoleon and the Secret War, London, John Murray, 2002.

57. Marianne CZISNIK, «Admiral Nelson's Tactics at the Battle of Trafalgar » dans History, 89 (2004), p. 549-559.

58. Richard woodman, The Victory of Seapower : Winning the Napoleonic War 1806-1814, London, Chatham, 1998.

59. Christopher D. HALL, « The Royal Navy and the Peninsular War », dans The Mariner's Mirror, 79 (1993), 403-18. Du même auteur, voir Wellington's Navy : Seapower and the Peninsular War 1807-14, London, Chatham, 2004.

60.Michael DUFFY, Roger MORRISS ed., The Glorious First of June 1794.

61.Brian SOUTHAM, Jane Austen and the Navy, London, Hambledon, 2000 ; J. PECK, Maritime Fiction. Sailors and the Sea in British and American Novels, 1719-1917, Basingstoke, Palgrave, 2001.

62. Margarette LINCOLN, Representing the Royal Navy. British Sea Power, 1750-1815, Aldershot, Ashgate, 2002. 


\section{AUTEUR}

\section{MARIANNE CZISNIK}

University of Edinburgh

School of History

Edinburgh, EH8 9JY, Ecosse, Royaume-Uni

czisnik@web.de 